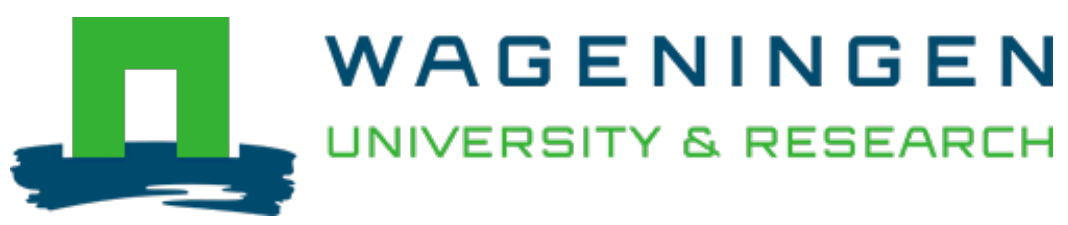

\author{
International medical travel, or medical tourism \\ International Encyclopedia of Human Geography \\ Ormond, M.E. \\ https://doi.org/10.1016/B978-0-08-102295-5.10283-5
}

This publication is made publicly available in the institutional repository of Wageningen University and Research, under the terms of article $25 \mathrm{fa}$ of the Dutch Copyright Act, also known as the Amendment Taverne. This has been done with explicit consent by the author.

Article $25 \mathrm{fa}$ states that the author of a short scientific work funded either wholly or partially by Dutch public funds is entitled to make that work publicly available for no consideration following a reasonable period of time after the work was first published, provided that clear reference is made to the source of the first publication of the work.

This publication is distributed under The Association of Universities in the Netherlands (VSNU) 'Article $25 \mathrm{fa}$ implementation' project. In this project research outputs of researchers employed by Dutch Universities that comply with the legal requirements of Article $25 \mathrm{fa}$ of the Dutch Copyright Act are distributed online and free of cost or other barriers in institutional repositories. Research outputs are distributed six months after their first online publication in the original published version and with proper attribution to the source of the original publication.

You are permitted to download and use the publication for personal purposes. All rights remain with the author(s) and / or copyright owner(s) of this work. Any use of the publication or parts of it other than authorised under article $25 \mathrm{fa}$ of the Dutch Copyright act is prohibited. Wageningen University \& Research and the author(s) of this publication shall not be held responsible or liable for any damages resulting from your (re)use of this publication.

For questions regarding the public availability of this publication please contact openscience.library@wur.nl 


\title{
International Medical Travel or Medical Tourism
}

\author{
Meghann Ormond, Wageningen University and Research, Wageningen, The Netherlands
}

(C) 2020 Elsevier Ltd. All rights reserved.

\begin{abstract}
Glossary
Biomedicine The dominant branch of medical science that applies biological and physiological principles to the diagnosis, treatment, and prevention of disease.

Biosociality The formation of social relationships and the production of identity based on genetic or biological conditions. Biotechnology The use of biological processes, organisms, or systems to manufacture products intended to improve the quality of human life.

Health system The organization of people, institutions, and resources that deliver health-care services to meet the health needs of target populations.

Health and wellness tourism Travel for the purpose of promoting health and well-being through physical, psychological, or spiritual activities.

In vitro fertilization A method of assisted reproduction in which a man's sperm and a woman's egg are fertilized in the laboratory and then transferred to the uterus of a woman for implantation and development.

International medical travel Travel for the purpose of obtaining biomedical treatment outside of one's country of residence. Medical disenfranchisement The legal and/or practical deprivation of access to biomedical diagnosis, treatment, and prevention.

Medical tourism A commonly used, politically charged term that both emphasizes the transgressive qualities of and undermines the desperation involved in traveling for the purpose of obtaining biomedical treatment outside of one's country of residence.

Medicalization A social process through which a previously normal human condition (behavioral, physiological, or emotional) becomes a medical problem in need of treatment by medical professionals.
\end{abstract}

Each year, it is estimated that millions of people around the world, disenfranchised by the restrictive national laws and unresponsive health systems in their countries of residence, circumvent these barriers by traveling to countries where their desired medical treatment is more accessible to them. Over the last decade, mainstream media coverage in patients' source and receiving countries alike has come to commonly describe these international flows of patients as "medical tourists." As such, treatment-specific phrases like "abortion tourism," "fertility tourism," "stem cell tourism," "pharmaceutical tourism," and even "euthanasia tourism" abound in reporting and discussions about people pursuing recognition of their medical wishes and care abroad. Yet, while the term "medical tourism" has gained significant traction in the popular press and among government and industry actors around the globe, numerous scholars over the last decade-echoing the voices of traveling patients themselves-have argued that the term "tourism," given its everyday associations with pleasure and frivolity, not only inadequately captures but also actively effaces patients' pain, desperation, and determination.

Scholars have also noted how the temporary nature of "tourism"-where the eventual return to one's "rightful" health and welfare jurisdiction is implicit-erodes or even rejects the burden of care a receiving country might have for those patients designated by its authorities as medical or health "tourists." In the United Kingdom's 2016 "Brexit" campaign, for instance, rightwing nationalist arguments seeking to deny immigrants' entitlement to health and social services vilified the European Union (EU) citizens living in the country as "health tourists," making "unfair" and "disproportionate" use of national socialized health resources.

The above examples demonstrate how the term "tourism," when associated with health care, comes to signal international health-care practices as highly transgressive acts. Variations in dominant ideologies underpinning national health and welfare systems and in the financial capacity of these systems determine the accessibility, affordability, and quality of care and treatment delivery for significant proportions of patients in their countries of residence. Given that the safeguarding and management of human health has largely been understood to take place within the container of the nation-state, international medical travel (IMT) - the more neutral descriptor we will use in the remainder of this entry in lieu of "medical tourism" - constitutes a challenging affront to the habitual moral and physical boundaries of one's presumed "rightful" country of residence.

Making use of the ideological pluralism across diverse national health and welfare systems, international patients pursue treatment in jurisdictions equipped for and open to handling specific medical needs. Irish women long traveled to the United Kingdom to terminate their unwanted pregnancies before the 2018 reversal of the abortion ban. Older British, German, and Italian women 
who no longer qualify for in vitro fertilization (IVF) in their home countries head to the Czech Republic or Spain, where age limits are higher, to undertake such procedures. Americans and Canadians with multiple sclerosis fly to Mexico or India for stem cell treatment not approved in their home countries. Indonesians regularly catch buses, flights, and ferries to Malaysia and Singapore to access reliable diagnostics, consult specialists, and purchase pharmaceuticals unavailable back home. Crossing borders for care deemed inaccessible to them in their countries of residence is thus a provocative practice that reveals the inability of patients' home health and welfare systems adequately to meet the needs of those who-for diverse reasons-may exceed the capacities, fall through the cracks, or have objectives that conflict with the dominant ideologies characteristic of those systems.

IMT provokes those whom it touches to contemplate the global diversity of ideological premises upon which core beliefs about and practices surrounding what constitutes human life, when life should begin and end, and whose life has greater value are formulated. It also challenges them to contemplate the extent to which they (must) agree or comply with the core beliefs and practices about life that dominate in the places in which they live. Finally, it prompts them to consider the consequences for both themselves and others of transgressing those geographically situated dominant core beliefs and practices. Because of its provocativeness on these three fronts, IMT has captured the public imagination, featuring not only in the popular press and political debates but also in books, television, and film. It has attracted the attention of diverse government, commercial, and civic actors around the globe concerned with health services, economic development, tourism, and transport. Unsurprisingly then, it has also developed as a significant field of study for health geographers, medical anthropologists and sociologists, health policy analysts, health economists, bioethicists, and business and management scholars.

\section{Patients Abroad}

IMT focuses explicitly on biomedical intervention and, therefore, is commonly distinguished from - though in practice often overlaps with-travel for the purpose of promoting health and well-being through physical, psychological, or spiritual activities (e.g., spas, complementary and alternative medicines, and antiaging and dieting regimens), a practice colloquially referred to as "health and wellness tourism." Estimating the dimensions of IMT is notoriously difficult. Reliable quantitative data is scarce because scholars, policymakers, and industry actors have yet to arrive at an operational definition, resulting in diverse recording practices in destinations receiving international patients. Given definitional challenges, destination hospitals' and governments' officially reported figures may lump together patients expressly traveling to a country temporarily for biomedical care together with travelers falling ill while on vacation who require emergency medical care and with locally resident immigrants excluded from subsidized care in these countries' public health systems.

Some scholars and policymakers prefer to focus on patients expressly traveling to a country temporarily for biomedical care paid for out of pocket by patients themselves (the so-called "real medical tourists") and their impacts on source and receiving countries' health systems. However, this practice overlooks two important groups of international patients. First, many people receive outsourced care abroad that has been financed by their national governments (e.g., Iraqi and Emirati patients in India, Libyan patients in Tunisia, and EU citizens in other EU countries with the use of the European Health Insurance Card or within the scope of Directive 2011/24/EU on cross-border health care). Second, because they may not qualify for subsidized care in their receiving countries' public health systems, many locally resident immigrants also engage with their source, receiving, and neighboring countries' health systems as long-term, part-time "medical tourists" (e.g., retirement migrants residing in Malaysia). Significant work remains to be done in order to better understand the medical and nonmedical resources on which these different international patient groups draw, as these may greatly differ depending on the nature and severity of their medical conditions and on where they are likely to receive follow-up care and to convalesce.

Despite these definitional challenges and the concomitant scarcity of reliable quantitative data about the volume of IMT, it is clear that growing numbers of government and private-sector health-care actors, most of which are located in the Global South, have eagerly turned to IMT as a way to improve their countries' economic and health conditions. Proponents argue that IMT has the potential to attract foreign revenue and investment, stem the international brain-drain of skilled health workers, improve local residents' access to specialized medical treatment and technologies, and provide a steady stream of paying patients to keep privatesector health-care providers afloat when local private health-care usage dips. Critics, meanwhile, argue that IMT may exacerbate receiving countries' already-existing health inequities by deviating finite health-care resources from the public sector to invest in and advance private-sector interests (e.g., skilled health workers shifting from the public to the private sector; fiscal incentives for the acquisition of high-end, specialist medical equipment and technologies used mostly by international patients). To date, however, little is known about the actual consequences of IMT on receiving countries, cities, and facilities and on local residents' access to biomedical care.

While some hospitals and clinics may individually promote themselves as "medical tourism" destinations, a growing array of destination actors also increasingly coordinates at national and subnational levels so that entire cities, regions, and countries can come to be recognized as therapeutic landscapes. The development and promotion of "medical tourism" in places as diverse as Dubai (United Arab Emirates), India, Jamaica, Japan, Jordan, Malaysia, the Philippines, Thailand, Singapore, and South Korea draws on what has become a standardized playbook. Governments focus on liberalizing their countries' health-care sectors by permitting health-care facilities to profit financially from patient care, authorizing foreign direct investment (FDI) in health care, and relaxing restrictions on health-care advertising. They may adjust immigration and entry regimes to meet the special needs of patients (e.g., multiple entry visas, longer stays, companion visas, and fast-tracking at immigration checkpoints). They may also 
avail a number of fiscal incentives and special land grants to spur private health-care providers to develop "world-class" medical facilities and services deemed attractive to international patients. Such efforts increasingly are accompanied by the establishment of a public/private-sector taskforce to promote the destination among target markets abroad, aid in the acquisition of nationally and internationally recognized accreditation for private health-care facilities, and ensure that both skilled health workers (e.g., nurses and physicians) and nonhealth workers (e.g., medical travel agents or facilitators) are duly trained and credentialed. Destination actors have yet to engage in any serious systematic assessment of the return-on-investment from these abovementioned efforts, however.

Government and industry actors in many "medical tourism" destinations early on sought to attract "medical tourists" from the Global North who had limited to nonexistent ties to their destinations for one-off, expensive surgeries (e.g., American patients going to India for cardiac procedures). However, these actors have eventually come to recognize that their destinations far more significantly and reliably depend on three other customer bases: emigrants visiting friends and relatives in their countries of origin, international patients from other Global South countries, and locally resident immigrants able to afford private health care. Emigrants visiting their countries of origin sometimes opt to take care of their health needs in more affordable and culturally and linguistically comfortable source country facilities while being able to benefit from local support networks. International patients from the Global South travel from near and far to other Global South destinations due to their geographical proximity, affordability, comparatively better health-care offerings, and more relaxed visa regimes. Locally resident immigrants, meanwhile, may prefer or need (e.g., if they are either no longer eligible for subsidized care in their countries of origin or not eligible for subsidized care in their receiving countries) to seek private health care in their countries of residence. The bulk of IMT, therefore, looks very different from early visions of "medical tourism."

\section{Patients at Home}

Patients' medical disenfranchisement in their countries of residence drives IMT. Medical disenfranchisement can be a result of financial barriers that inhibit individuals. In home country health systems where the dominant ideology deems health care a "private good," prohibitive out-of-pocket health-care costs may put medical treatment out of reach for those in the middle and lower socioeconomic classes (e.g., middle-class Americans who cannot afford adequate private health insurance coverage yet who also do not have an income low enough to qualify for public health insurance (such as Medicaid in the United States)). Likewise, national health systems that ostensibly consider health care a "public good" but are poorly financed, managed, and equipped force patients into economic hardship when pursuing care in the private sector. We see, for instance, more and more nationals in Global South countries with growing middle classes (e.g., Indonesia and Nigeria) who travel abroad to access diagnostics, procedures, and medication that, while costing the same or even higher than in their home countries' private sectors, they believe they can more fully trust. They contrast their care abroad with ill-equipped national health systems back at home where specific biomedical expertise, equipment, and technologies are lacking or inadequately distributed. As briefly noted in the introduction, people also cross borders to circumvent national ideologies that restrict or prohibit specific treatments and procedures due to limited supply (e.g., organ transplantation), dominant moral perspectives (e.g., preimplantation sex selection of embryos for IVF, abortion, and euthanasia), or the procedure or product's experimental or unregulated status (e.g., stem cell treatment and pharmaceuticals).

Early proponents of IMT framed it as a convenient, temporary way to reduce pressure on overburdened national health systems in international patients' home countries. Because IMT is not unidirectional, however, patients returning to their countries of residence may also constitute a risk to the local population (e.g., developing microbial resistance during their hospital stay abroad) and a burden on their national health systems when home country doctors, with limited access to reliable records of their patients' medical procedures undertaken abroad, are underprepared to ensure appropriate continuity of care and address potential complications. Furthermore, in circumventing national laws by going abroad, their acts may be criminalized upon return to their home jurisdictions (e.g., Australia's criminalization of commercial surrogacy after the 2014 "Baby Gammy" affair and the ensuing denial of an Australian passport to children of Australian citizens who are born to commercial surrogates abroad).

As the phenomenon has grown in volume and intensity, international patients from Global South countries with ill-equipped and underfunded health systems have increasingly been targeted and openly shamed by local politicians and press for "unpatriotically" abandoning their national health systems and letting them decline further instead of investing in them as demanding publicsector users and private-sector consumers. This argument-ironically made by politicians who themselves routinely travel abroad for medical care-is short-sighted, however, as international patients rarely completely disengage from their home country health systems. Like emigrants returning to their countries of origin after years abroad, international patients can and do engage in knowledge transfer, using their insight gleaned from their brief periods abroad to demand higher-quality medical facilities, services, and products back at home. Indeed, research suggests that international patients learn to become more discerning health-care consumers by engaging in IMT, a transformation that has been especially challenging in countries with national health services like Canada and the United Kingdom where patients are traditionally understood as public service users and not private consumers.

Yet international patients engage in IMT no longer only as national citizens but now also as members of transnational biosocial networks. The term "biosocialities" denotes postnational affiliations and networks that coalesce around certain biological or health conditions (e.g., people living with multiple sclerosis or breast cancer) and medical procedures (e.g., people who have undertaken cosmetic surgery or stem cell treatment). IMT constitutes a biosocial practice that draws on a web of veteran and prospective patients and their families as well as advocates, and for- and not-for-profit care providers around the world. It is a collective practice that 
enables patients to overcome their disenfranchisement through the organizational, emotional, and financial support their members provide. Unlike idealized familial or national bonds, however, it is not a web of altruistic allegiances. While Chinese nationals cannot visit mainland South Korea as tourists, for instance, those who have specific preapproved medical needs (i.e., profitable health problems) are permitted to enter South Korea on a "medical tourist" visa, pending proof of diagnosis of their ailments from trusted doctors abroad and of ability to pay for their stay and treatment.

\section{Toward a Critical Geography of International Medical Travel}

Much early geographical scholarship on IMT focused on what led diverse Global South locations to emerge as global health-care hubs. The key factors in flattening the global medical "playing field" were found to be economic globalization, significant advancements in both telecommunications and medical (bio)technology, and cheaper international travel. From the 1990s onward, many Global South countries were required by international development banks as a condition for their loans to adhere to neoliberal trade policies that ushered in or served to intensify the privatization of key public services like health care. Trade policies like the World Trade Organization's 1995 General Agreement on Trade in Services (GATS) that facilitated international flows of people, goods, and services led to significant growth in foreign direct investment in medical facilities, greater recourse to off-shoring medical diagnostics, reduced import tariffs on high-end medical equipment and pharmaceuticals, reduced entry barriers for foreign skilled health workers to practice abroad, and reduced travel restrictions on patient-consumers seeking care abroad. A slew of new clinics and hospitals equipped with the most cutting-edge medical technologies emerged in the Global South, challenging conventional imaginaries about where medical expertise and technology is-and can be-concentrated in the world.

At the same time, many health and social care systems in the Global North were themselves undergoing significant overhauls, with deinstitutionalization, privatization, and self-responsibilization for one's own health becoming de rigueur. Health-care costs were rising in Global North countries as a result of rapidly aging populations and the encroaching medicalization of everyday life, where bodies were increasingly understood as sites of intervention that could be medically improved on and natural processes like aging were increasingly pathologized. It became apparent by the mid-2000s that this new supply of medical facilities in the Global South had the potential to compete with facilities in the Global North for custom by offering medical treatment that was significantly cheaper than in Global North patients' home countries due to currency exchange and wage differentials. Indeed, Global South governments and private-sector actors alike were enthralled with the possibility of attracting comparatively wealthy Global North patients to facilities in their countries.

Geographical scholarship, most of which came and continues to come out of the Global North, accompanied these trends starting in the mid-2000s. Though patients from the Global South had long been traveling to the Global North for medical care, the volume of scholarship on South-North IMT is minimal compared with scholarship on North-South IMT. Geographers were not only busy describing the global distribution of biotechnological advancements and biomedical specializations that spurred and accompanied these North-South flows (e.g., cosmetic surgery in Brazil and South Africa, gender reassignment procedures in Thailand, cardiac and joint-replacement procedures in India, dental procedures in Hungary and Mexico, and kidney transplantation in the Philippines), they were also deeply concerned about the potential risks that North-South IMT posed to populations in both the Global North and South. Tapping into work on international political economy, geographies of care and responsibility, and health equity, geographers especially focused on the ways in which these novel Global North-South relational geographies created conditions ripe for the neocolonial exploitation of people in the Global South, through the impoverishment of the health systems upon which people in the Global South heavily rely but also through the use of their bodies and body parts (e.g., commercial surrogacy and organ harvesting). Science and technology studies (STS) scholars, for example, observed how biotechnical advancements (e.g., immunosuppressant drugs that keep recipients' bodies from rejecting transplanted organs) vastly expanded the number of compatible donors beyond close relatives and people with similar genetic backgrounds to include much more distant others.

A second wave of geographical scholarship on IMT emerged in the mid-2010s as a result of growing recognition among scholars doing extensive empirical work in Global South IMT destinations that the actual volume and scale of North-South IMT is far less significant in most destinations than South-South IMT, where Global South patients travel to other Global South countries for medical treatment. Attending more closely to actually existing IMT flows instead of IMT destinations' development aspirations has led these scholars to decenter attention from the drivers, obstacles, and practices associated with North-South IMT by including those associated with South-South IMT as well. Key differences between these two groups include the degree of home health system disenfranchisement, the ease with which they may travel and enter another country for medical treatment, and the capital available to them to cover the financial and social costs associated with IMT. Consider, for example, that IMT is generally a one-off event for North-South patients. While Global North patients can usually afford to cover their routine health-care needs at home, they may travel to the Global South once for a specific surgery or treatment just out of their reach back home. By contrast, much South-South IMT is for both routine and complicated health-care needs, with patients traveling more frequently across borders to meet those needs. Likewise, numerous inexpensive, informal, and often communal accommodation options exist in IMT destinations for South-South patients and travel companions who are unable to cover the costs of a hotel or serviced apartment normally affordable for North-South patients due to foreign currency exchange rates, leading to a range of significant knock-on effects in destinations' local housing markets and economies. South-South patient mobility also throws into sharp relief the significant role of international aid and non/paragovernmental development schemes in Global South patients' health-care access and practices as well as the role of emerging forms of South-South competition and solidarity (e.g., the Southern African Development Community 
(SADC) and Association of Southeast Asian Nations' (ASEAN) intraregional health-care governance arrangements). In studying the different challenges and experiences faced by South-South patients, second-wave scholars have increasingly identified facets, spatialities, and consequences of IMT previously overlooked in literature largely oriented to debates and concerns in the Global North and, in so doing, complicated dominant understandings about IMT.

As with most emerging fields of study, there are several gaps in existing knowledge. Specifically, while there has been a significant shift toward studying the experiences of both Global North and South patients, research has largely focused on the international health-care pursuits of economically active aged adults, to the exclusion of both children and young people and-despite the growing social and economic challenges facing rapidly aging populations around the world-seniors. Future research should examine more fully the linkages between IMT and seniors' international mobility driven, at least in part, by unmet long-term care needs in their countries of residence. How do shifting visions and practices of citizenship and belonging transform transnational mobility, health, and care relationships along the life-course? Indeed, because IMT has become an increasingly important tool for compensating for national medical disenfranchisement, there is need for rigorous comparative cross-sectional and longitudinal research on IMT's local economic and health system impacts in both source and receiving countries. Finally, there is much to be gained from more geographers taking up IMT as a useful lens through which to critically examine the mediating role of the biological human body in (inter)national and global, postnational forms of resistance, solidarity, care, and hospitality.

See Also: Therapeutic Landscapes; Gender and Health; Health and Development; Health Geography; Health Inequalities; Healthcare Accessibility; Place and Health; Tourism; Migration.

\section{Further Reading}

Bell, D., Holliday, R., Ormond, M., Mainil, T., 2015. Transnational healthcare, cross-border perspectives. Soc. Sci. Med. 124, 284-289.

Chee, H.L., Whittaker, A., Yeoh, B.S., 2017. International medical travel and the politics of transnational mobility in Asia. Asia Pac. Viewp. 58, 129-135.

Connell, J., 2006. Medical tourism: Sea, sun, sand and... surgery. Tour. Manag. 27, 1093-1100.

Connell, J., 2011. Medical Tourism. CABI, Wallingford.

Crooks, V.A., Kingsbury, P., Snyder, J., Johnston, R., 2010. What is known about the patient's experience of medical tourism? A scoping review. BMC Health Serv. Res. 10, 266 https://doi.org/10.1186/1472-6963-10-266.

Hall, C.M. (Ed.), 2012. Medical Tourism: The Ethics, Regulation, and Marketing of Health Mobility. Routledge, Abingdon.

Holliday, R., Bell, D., Cheung, 0., Jones, M., Probyn, E., 2015. Brief encounters: assembling cosmetic surgery tourism. Soc. Sci. Med. 124, 298-304.

Holliday, R., Jones, M., Bell, D., 2019. Beautyscapes. Manchester University Press, Manchester.

Johnston, R., Crooks, V.A., Snyder, J., Kingsbury, P., 2010. What is known about the effects of medical tourism in destination and departure countries? A scoping review. Int. J. Equity Health 9, 24. https://doi.org/10.1186/1475-9276-9-24.

Kangas, B., 2002. Therapeutic itineraries in a global world: Yemenis and their search for biomedical treatment abroad. Med. Anthropol. 21, 35-78.

Lunt, N., Horsfall, D., Hanefeld, J. (Eds.), 2015. Handbook on Medical Tourism and Patient Mobility. Edward Elgar, London.

Ormond, M., 2013. Neoliberal Governance and International Medical Travel in Malaysia. Routledge, Abingdon.

Ormond, M., Kaspar, H., 2018. South-South medical tourism. In: Fiddian-Qasmiyeh, E., Daley, P. (Eds.), Routledge Handbook of South-South Relations. Routledge, Abingdon, pp. 397-405.

Parry, B., Greenhough, B., Brown, T., Dyck, E.P.I. (Eds.), 2015. Bodies across Borders: The Global Circulation of Body Parts, Medical Tourists and Professionals. Ashgate Publishing, Ltd, London.

Pennings, G., 2002. Reproductive tourism as moral pluralism in motion. J. Med. Ethics 28, 337-341.

\section{Relevant Websites}

International Medical Travel Journal. https://www.imtj.com/.

Medical Mobilities. http://medicalmobilities. blogspot.com/.

Medical Tourism Research Group. http://www.sfu.ca/medicaltourism/. 